\title{
SPATS2L wt Allele
}

National Cancer Institute

\section{Source}

National Cancer Institute. SPATS2L wt Allele. NCI Thesaurus. Code C113528.

Human SPAT S2L wild-type allele is located in the vicinity of 2 q33.1 and is approximately $201 \mathrm{~kb}$ in length. This allele, which encodes SPAT S2-like protein, plays a role in protecting myoblasts from oxidative stress. 